\title{
Епідемічна ситуація щодо туберкульозу у Волинській області
}

\section{Валецький Ю.М.1,4, Валецька Р.0. ${ }^{2,4}$, Комар 0.І. ${ }^{1}$, Симонюк Л.І. ${ }^{3}$}

1. КП «Волинський обласний фтизіопульмонологічний медичний центр», м. Луцьк, Україна

2. КП «Волинська обласна клінічна лікарня», м. Луцьк, Україна

3. КП «Волинський обласний центр громадського здоров'я», м. Луцьк, Україна

4. Львівський національний медичний університет ім. Данила Галицького, м. Львів, Україна

Протягом 2020 р. на всі форми активного туберкульозу (ТБ) у Волинській області (нові випадки та рецидиви) захворіли 499 осіб, що становить 48,51 на 100 тис. населення (у 2019 р. 664 хворих, або 64,11 на 100 тис. населення). Захворюваність знизилася на 24,3 \%. Показник рецидивів ТБ знизився на 24,5 \%, що становить 10,60 на 100 тис. населення (у 2019 р.14,04 на 100 тис. населення). Захворюваність на вперше діагностований ТБ в області знизилася на 24,6 \%: із 50,26 до 37,91 на 100 тис. населення. Захворюваність на ТБ органів дихання знизилася на 23,3 \%: із 45,52 до 34,90 на 100 тис. населення; на 25,7 \% знизилася захворюваність на позалегеневі форми ТБ: із 8,23 у 2019 р. до 6,10 на 100 тис. у 2020 р.

Захворюваність на активний ТБ легень становила 31,79 на 100 тис. населення (у 2019 р. - 42,03 на 100 тис. населення), тобто відбулося зниження на 24,4 \%. Захворюваність на деструктивні форми ТБ легень знизилася на 25,5 \%: із 21,01 на 100 тис. населення у 2019 р. до 15,65 на 100 тис. населення у 2020 р., хоча питома вага деструктивного ТБ серед уперше виявлених випадків знизилася на 0,8 \% (із 50,0 \% у 2019 р. до 49,02 \% у 2020 р.). Захворюваність на бацилярні форми ТБ знизилася на 25,0%: у 2019 р. - 36,12 на 100 тис., у 2020 р. - 27,02 на 100 тис. На 0,9 \% знизилася питома вага бацилярного ТБ серед нових випадків ТБ легень (85,0%).
Захворюваність на активний ТБ серед дітей віком 0-14 років зросла порівняно 32019 р. на 17,9 \%: із 5,86 (12 дітей) до 6,91 (14 дітей) на 100 тис. Захворюваність на активний ТБ серед дітей віком 15-17 років зросла в 5,8 раза: з 2,97 (1 підліток) до 17,26 (6 підлітків) на 100 тис.

Захворюваність на коінфекцію ТБ/ВІЛ знизилася на 11,6 \% і становить 3,60 на 100 тис. населення проти 4,07 на 100 тис. населення у 2019 р.

Станом на 01.01.2021 у Волинській області на обліку в протитуберкульозних закладах перебуває 440 хворих на всі форми активного ТБ (у 2019 р. - 636). Поширеність дорівнює 42,77 на 100 тис. населення (в тому числі в дітей віком 0-14 років - 4,94, віком 15-17 років - 14,38). Зниження показника відбулося на 30,6 \%.

Висновки. 1. У Волинській області у 2020 р. спостерігалося зниження захворюваності на ТБ. 2. Відзначається недовиявлення хворих на ТБ на рівні первинної ланки медичної допомоги, підтвердження діагнозу відбувалося при пізньому зверненні по медичну допомогу хворих із задавненими випадками ТБ. 3. Припускаємо, що найближчими роками через пандемію COVID-19 може погіршитися епідемічна ситуація щодо ТБ. 